\title{
The Specifics of the Relationship between Job Satisfaction and Efficacy Evaluation of Representatives of «Person - Technics» Group of Professions
}

\section{Особливості зв'язку між задоволеністю роботою та оцінкою ефективності представників групи професій «людина - техніка»

\author{
Svitlana Motsna \\ Student
} \\ Світлана Моцна \\ студентка}

\author{
E-mail: motsnaja@i.ua \\ orcid.org/0000-0002-4181-6888 \\ Researcher ID: A-8062-2019
}

Oles Honchar Dnipro National

University, Ukraine

72, Haharina avenue, Dnipro, 49000

Oxana Bayer

Ph. D. in Psychology,

Assistant Professor
Дніпровський нащіональний університет ілені Олеся

Гончара, Україна проспект Гагаріна, 72,

м. Дніпро, 49000

Оксана Байєр кандидат психологічних наук, доцент

E-mail: bayeroxana@gmail.com orcid.org/0000-0002-0651-1472

Researcher ID: C-9394-2016

Oles Honchar Dnipro National University, Ukraine

72, Haharina avenue, Dnipro, 49000
Дніпровський національний університет ілені Олеся

Гончара, Україна проспект Гагаріна, 72,

м. Дніпро, 49000 
Original manuscript received December 24, 2018

Revised manuscript accepted January 31, 2019

\section{ABSTRACT}

The paper deals with the study of the factors related to efficacy of technical professionals. Theoretical analysis brings up job satisfaction and job involvement as such influential determinants.

According to the hypothesis of the empirical research, there is a relationship between the efficacy and the job satisfaction. The sample included 40 gas equipment fitters and 4 their direct managers. The hypothesis was verified using Job Satisfaction Survey by R. Spector, Job Involvement Questionnaire by R. N. Kanungo, and the questionnaire for employee efficiency assessment by $M$. A. Shevchenko. We chose double-assessment of fitters' efficacy when both employees and their managers evaluated how efficient an employee was as this helped to eliminate the factor of subjectiveness. Unfortunately, there is still no assessment form measuring the efficacy of gas equipment fitters objectively.

The quasi-experiment was chosen as a research plan. The methods of processing the empirical data included descriptive statistics, $\rho$-Spearman correlational analysis, and $\varphi^{*}$ Fischer test.

The results showed that efficacy evaluation are related to the level of job satisfaction and job involvement. There are meaningful correlations of efficacy evaluation with salary satisfaction, promotion satisfaction, additional concessions satisfaction, rewards satisfaction, and the character of work satisfaction. There are no correlations of efficacy evaluation with job conditions satisfaction, relations with colleagues satisfaction, and awareness satisfaction.

Employees with higher levels of efficacy evaluation are also typical of higher job satisfaction and involvement. The practical application of the research lies in its potential value for personnel managers and HR-departments in selecting employees relevant for such a group of professions as well as motivating those who work for being more satisfied and thus efficient.

Key words: "person - technics» group of professions, efficacy, efficacy evaluation, job satisfaction.

\section{Вступ}

У психології праці проблема ефективності діяльності завжди знаходилась у центрі уваги. В останнє десятиліття 
це питання набуло особливої гостроти, що пов'язано з глибокими соціальними перетвореннями, інтенсифікацією всіх сторін економічного життя суспільства, які створюють потребу в високоефективних працівниках різних сфер діяльності. Загострилися протиріччя, що існують між вимогою підвищення якості продукції та скороченням чисельності відповідальних за це фахівців. Роботодавці пред'являють усе вищі вимоги як до рівня освіти, професійної компетентності, результативності діяльності, так і до особистісних якостей представників групи професій «людина - техніка». Виникає потреба пошуку засобів ефективного стимулювання високої продуктивності праці персоналу, підвищення його задоволеності роботою, зацікавленості в ній і прихильності організації.

Особливості специфіки зв'язку між задоволеністю працею фахівця і його об'єктивною виробничою поведінкою, особливо з ефективністю, є постійно актуальним предметом дослідження. Питання про зв'язок між задоволеністю роботою й ефективністю до теперішнього часу не знаходить однозначного вирішення, оскільки численні дослідження, проведені в цьому напрямку в різних країнах, дають найсуперечливіші результати (J. Kaаp-Deeder, 2018).

Задоволеність працею - це стан збалансованості вимог, що пред’являються працівником до змісту, характеру й умов праці, та суб’єктивної оцінки можливостей реалізації цих запитів. Це оціночне ставлення людини до власної трудової діяльності, різних їі аспектів, найважливіший показник адаптації працівника на даному підприємстві, в певній трудовій організації. Розрізняють так звану загальну і часткову задоволеність працею, де перша характеризує задоволеність загалом, а друга - різними аспектами праці й елементами виробничої ситуації (C. Ryff, 1995). Визначення складових, які позитивно чи негативно впливають на ставлення професіоналів до роботи, є важливим для прийняття рішень у галузі управління персоналом, підвищення ефективності праці та функціонування вироб- 
ництва. Це обумовлює актуальність оцінювання та покращення рівня задоволеності працею як важливого показника ставлення фахівців до роботи.

Із задоволеністю трудовою діяльністю пов'язані такі особистісні характеристики працівників, як когнітивні здібності, емоційна стійкість, а також досвід у професії, перспектива вживання надбаних умінь і навичок тощо.

Ефективність роботи є комплексною характеристикою діяльності фахівця, на яку впливають властивості людини як особистості. Ефективність роботи представників групи професій «людина - техніка» може бути вираженою в кількісно-якісних показниках та отриманні матеріальних продуктів праці, що відповідають вимогам суспільства (ЗимняЯ, 2004).

Задоволеність працею, будучи важливою базою формування та реалізації сприятливої психологічної атмосфери у робочому колективі, є дуже вагомим складником соціально-психологічного клімату на виробництві (J. KаарDeeder, 2018). На задоволеності роботою позначається як співвідношення між мотивацією та характером побажань фахівців, так і їх ефективність у професійній діяльності (Статінова, 2001).

Автори, які займаються вивченням зв’язку між задоволеністю працею і продуктивністю праці, по-різному підходять до вирішення цього питання.

Розглядаючи цю проблему докладніше, важливо зауважити, що одна з початкових спроб вирішити обговорюване питання щодо особливостей зв' язку між задоволеністю роботою та оцінкою ефективності представників групи професій «людина - техніка» призводить до створення так званої школи «людських відносин». Основне положення цієї теорії говорить про те, що сприятливий психологічний клімат підвищує продуктивність праці представників групи професій «людина - техніка» більшою мірою, ніж традиційні економічні чинники. Виникла ця теорія в ході дослідження, метою якого було з'ясувати, як чинники зо- 
внішнього середовища впливають на продуктивність праці. Експерименти на заводах компанії «Вестерн електрик» у Хоторні показали, що поліпшення психологічного клімату збільшує задоволеність працею, яка, в свою чергу, призводить до зростання ефективності (C. Ryff, 1995).

Цією проблемою займалися також і вітчизняні вчені. Зокрема, Л. А. Онуфрієва за результатами дослідження зазначає, «... що проблема саморозвитку та самореалізації $\epsilon$ значущою у багатьох сучасних концепціях розвитку людини, а актуальна потреба саморозвитку, прагнення до самовдосконалення є цінними вже самі по собі та є показником особистісної зрілості й водночас умовою її досягнення»; та робить висновок, «... що постійне прагнення до саморозвитку приносить і закріплює успіх у професійній діяльності та сприяє професійному довголіттю особистості» (Онуфрієва, 2016). Дослідниця підтверджує, що важливою складовою професійної «Я-концепції» $є$ професійна самосвідомість, що обумовлює саморегуляцію особистістю своїх дій у професійній сфері на основі пізнання професійних вимог, своїх професійних можливостей та емоційно-ціннісного ставлення до себе як до суб’єкта конкретної професійної діяльності (Онуфрієва, 2018).

В. Г. Панок досліджував питання, як саме психологічний клімат у бригадах впливає на загальну задоволеність працею, і як вона позначається на продуктивності праці. У результаті експериментів, проведених під час дослідження, вчений дійшов висновку, що поліпшення психологічного клімату в бригадах призводить до зростання задоволеності працею, яка викликає зростання ефективності (Панок, 1999).

Отже, можна побачити, що часткова задоволеність певним чином може бути пов'язана із загальною задоволеністю працею й ефективністю, але який саме характер зв' язку між цими трьома змінними, вивчено не до кінця. Відомо, що задоволеність окремими елементами умов і організації 
праці, психологічним кліматом значуще корелює із загальною задоволеністю працею (Статінова, 2001).

Установлено також, що приватна задоволеність може бути пов'язана 3 ефективністю. Так, якщо розглядати психологічний клімат, отримано дані, які свідчать, що в трудових групах зі сприятливим психологічним кліматом продуктивність праці вища на 15-40\%, ніж у групах із несприятливим кліматом (Ј. Kaаp-Deeder, 2018).

Але цей і подібні йому факти не дають змоги прямо пояснити характер зв'язку між частковою і загальною задоволеністю працею, між цими видами задоволеності й продуктивністю. Більш того, деякі дослідники вважають, що наявність кореляції між частковою і загальною задоволеністю працею ще не доводить, що деяка сукупність чинників часткової задоволеності працею може бути зведена до загальної задоволеності працею. Так, Н. П. Статінова вважає, що загальна задоволеність не є агрегацією часткової задоволеності, вона являє собою самостійну оцінку, пов'язану з іншими елементами орієнтування (Статінова, 2001).

У питанні щодо зв'язку між частковою задоволеністю та ефективністю існує більша, хоча і не повна визначеність. Відомо, що внаслідок проведення окремих заходів із метою поліпшення умов і організації праці може одночасно збільшуватися й задоволеність цим аспектом виробничої ситуаціï, й ефективність (C. Ryff, 1995). Однак, пізніше можливе деяке зменшення ефективності або їі повне зниження до рівня, що відповідає тому, який був до початку проведення заходів (Штепа, 2018).

Залежно від специфіки виробництва оптимізація таких параметрів умов праці, як рівень шуму, вібрація, освітленість, температура тощо, може мати стабільний позитивний вплив на ефективність працівників. У тих же випадках, коли ті заходи, що проводяться для поліпшення умов праці, безпосередньо не оптимізують трудову діяльність, вони можуть мати тимчасовий вплив на ефективність за рахунок «ефекту новизни» (Панок, 1999). Отже, 
щодо впливу заходів із метою поліпшення організації праці можна підсумувати, що у разі своєї адекватності, коли вони за своїм змістом є заходами, спрямованими саме на збільшення продуктивності праці, такі заходи мають стабільний позитивний вплив на ефективність.

Щодо питання про зв’язок між загальною задоволеністю працею та ефективністю існують різні підходи до аналізу цієї проблеми. Пояснюючи задоволеність працею як оцінку того, наскільки повно у виробничій ситуації здійснюються очікування індивіда, Л. Портер і його колега Е. Лоутар висунули свою так звану «теорію очікувань», у якій доводять, що не збільшення задоволеності веде до зростання продуктивності, а зростання продуктивності може привести до підвищення винагород, які й здатні викликати збільшення задоволеності (C. Ryff, 1995).

Теорія очікувань пояснює низьку кореляцію між продуктивністю і задоволеністю працею або її відсутність так: багато робітників можуть отримувати у процесі їх праці ті винагороди, які мають незначне відношення до виконуваної ними роботи i, зокрема, до продуктивності праці. Наприклад, деякі працівники можуть отримувати задоволення, розмовляючи зі своїми колегами, хоча це і збільшує їх задоволеність працею, але необов'язково викликає збільшення ефективності. Зв'язок між задоволеністю і продуктивністю праці існує, але тільки у вигляді зв'язку між мотивами й ефективністю (Мадди, 2005). Між гігієнічними чинниками й ефективністю зв'язок відсутній. Невдачі в спробах виявити зв'язок між ефективністю і задоволеністю пояснюються неправильністю вимірювання задоволеності, оскільки зазвичай шукають зв'язок між ефективністю і загальною задоволеністю, куди входить задоволеність гігієнічними чинниками, тоді як необхідно вимірювати зв'язок тільки між задоволеністю мотиваторами й ефективністю (J. Kaаp-Deeder, 2018).

Слід зазначити, що у дослідженнях позитивний зв'язок між загальною задоволеністю і продуктивністю, можливо, 
пояснюється тим, що в робітників домінуючим елементом у структурі задоволеності працею є задоволеність функціональним змістом праці (Мадди, 2005). До того ж, у деяких дослідженнях негативний зв'язок між загальною задоволеністю працею і продуктивністю обумовлюється особливостями конкретної виробничої ситуації, тобто поганим станом умов і організації праці, які здатні впливати на загальну задоволеність працею (Дж. Равен, 2002).

Поліпшення умов та організації праці оптимізує виконання робочих операцій i викликає збільшення ефективності й задоволеності виробничою ситуацією, що впливає на загальну задоволеність працею. Відповідність індивідуально-психологічних характеристик особистості змісту праці також впливає на ефективність i, через задоволеність змістом роботи, на загальну задоволеність працею.

У нашій роботі досліджується зв'язок задоволеності роботою слюсарів із ремонту й експлуатації газового устаткування та оцінки їх ефективності. Емпіричним шляхом доведено наявність зв'язку між ступенем задоволеності роботою слюсарів і сумарною оцінкою їх ефективності (тобто сумою їх суб’ єктивної оцінки ефективності й оцінки ефективності з боку їх безпосередніх керівників).

Мета статті - визначити особливості зв' язку між оцінкою ефективності та задоволеністю роботою представників групи професій «людина - техніка» на прикладі слюсарів із ремонту й експлуатації газового устаткування.

\section{Завдання статті}

1. Здійснити теоретичний аналіз проблеми особливостей зв' язку оцінки ефективності та задоволеності роботою представників групи професій «людина - техніка» .

2. Провести емпіричне дослідження особливостей зв' язку оцінки ефективності та задоволеності роботою представників групи професій «людина - техніка» на прикладі слюсарів із ремонту й експлуатації газового устаткування. 


\section{Методи та методики дослідження}

Кониептуальною гіпотезою дослідження стало припущення про те, що для представників групи професій «людина - техніка» характерними є певні особливості зв'язку між задоволеністю роботою та ефективністю.

Елпірична гіпотеза: працівникам із високими показниками технічного й емоційного типів інтелекту і толерантності до невизначеності притаманні вищі рівні ефективності та задоволеності своєю роботою.

Вибірка досліджуваних складалась зі співробітників ПАТ «Дніпрогаз» м. Дніпра, чоловіків віком від 30 до 45 років. Загальна кількість опитаних слюсарів із ремонту й експлуатації газового устаткування склала 40 осіб. Для підвищення достовірності результатів дослідження проводилось анонімно (досліджуваних просили вказати тільки вік, стать та ініціали). Також із метою експертної оцінки ефективності праці додатково було залучено 4 керівники, що є важливим для нашого дослідження, оскільки погляди фахівців і керівників на оцінку різних аспектів ефективності робітників можуть різнитися. Такий методичний прийом уможливив нам певною мірою нівелювати чинник суб'єктивності як самих працівників, так і їх керівників.

Наведемо коротку характеристику й опис використовуваних у дослідженні психодіагностичних інструментів.

Для визначення особливостей задоволеності роботою було проведено дослідження за «Опитувальником задоволеності роботою» (Job Satisfaction Survey; JSS), розробленим Р. Спектором у 1985 р. (R. Mansfield, 1996). Методика оцінює афективну реакцію індивіда на роботу та їі специфічні аспекти. Опитувальник уміщує 36 тверджень і вимірює задоволеність 9 аспектами роботи: зарплатнею, просуванням, керівництвом, додатковими пільгами і виплатами, винагородами, умовами виконання, колегами, характером роботи й інформуванням.

Із метою виявлення рівня залученості слюсарів із ремонту й експлуатації газового устаткування у роботу було 
використано «Опитувальник залученості у роботу» (Job Involvement Questionnaire; JIQ), розроблений Н. Канунго у 1982 p. (R. Mansfield, 1996). Методика вміщує 10 тверджень і вимірює ступінь, за яким індивід психологічно ідентифікується зі своєю роботою. Залученість до роботи це той інтегральний чинник, у якому відображаються трудові цінності, професійна етика працівників, їх мотивація та задоволеність працею. 3 рівнем залученості працівників пов'язані відповідні установки, що визначають ставлення фахівців до роботи, клієнтів, керівництва й організації загалом.

Для оцінки ефективності робітників було використано опитувальник, розроблений менеджером по роботі з персоналом ПАТ «Дніпрогаз» М. А. Шевченком у 2015 р. Опитувальник містить шкали оцінки робітника керівником, а також самооцінки. Оцінювалися такі показники, як компетентність, відповідальність за якість роботи, дисципліна, прагнення до самовдосконалення, орієнтація на споживача, ініціативність. Нагадаємо, що такий опитувальник заповнювався як самими робітниками, так і їх безпосередніми керівниками. Для аналізу було взято «інтегральний показник ефективності», який обчислювався як сума двох оцінок.

Методи обробки результатів емпіричного дослідження вміщували дескриптивну статистику, кореляційний аналіз за критерієм $\rho$-Спірмена та пошук розбіжностей між контрастними підгрупами досліджуваних за критерієм кутового перетворення $\varphi *$-Фішера.

Дослідження проводилось у червні-липні 2018 р. Його результати представлено у наступному підрозділі статті.

\section{Результати та дискусії}

Отримані дані емпіричного дослідження зведено у таблицю сирих балів. За ними було підраховано середнє арифметичне, дисперсію та стандартне відхилення. Середній 
показник $\bar{x}$ щодо задоволеності роботою у робітників дорівнює 127,55 бала $(\max =156$ i $\min =96) ; \bar{x}$ ефективності фахівців дорівнює 244,2 бала $(\max =292$ i $\min =205)$; величина $\bar{x}$ толерантності до невизначеності у робітників дорівнюе $52,525(\max =67 \mathrm{i} \min =35)$.

Обрахування $\bar{x}$ та $\sigma$ дозволило нам надалі сформувати підгрупи досліджуваних із різними рівнями ефективності, задоволеності роботою та різними індивідуально-психологічними характеристиками задля їх співставлення, що буде описано далі.

Із метою дослідження зв'язків між особливостями задоволеності роботою й ефективністю представників групи професій «людина - техніка» нами було проведено кореляційний аналіз за коефіцієнтом кореляції $\rho$-Спірмена. Показник «сумарна задоволеність» було підраховано як суму складників задоволеності роботою, які вимірювались за «Опитувальником задоволеності роботою» .

У результаті емпіричного дослідження було виявлено прямий значущий зв' язок високого рівня оцінки ефективності з рівнем задоволеності роботою $(\rho=0,94$ за $\mathrm{p} \leq 0,001)$ і залученості в роботу ( $\rho=0,91$ за $\mathrm{p} \leq 0,001)$. Для початку нами було проаналізовано зв'язок задоволеності роботою й інтегральний показник оцінки ефективності, що обраховувався як сума суб'єктивної оцінки власної ефективності з боку самих працівників та оцінки ефективності працівника, наданої його безпосереднім керівником. Варто наголосити на зв'язку між такими аспектами задоволеності роботою й оцінкою ефективності, як заробітна платня ( $\rho=0,58$ за $\mathrm{p} \leq 0,05)$, просування $(\rho=0,61$ за $\mathrm{p} \leq 0,05)$, додаткові пільги ( $\rho=0,82$ за $\mathrm{p} \leq 0,001)$, винагороди, що залежать від різних чинників $(\rho=0,86$ за $\mathrm{p} \leq 0,001)$, і характер роботи $(\rho=0,88$ за $\mathrm{p} \leq 0,001)$. Результати емпіричного дослідження у вигляді даних кореляційного аналізу за критерієм  
Таблиця 1. Особливості зв'язку оцінки ефективності праці та задоволеності професійною діяльністю представників групи професій «людина - техніка» (за коефіцієнтом кореляції $\rho$-Спірмена)

\begin{tabular}{|c|c|c|c|c|c|c|c|c|c|c|c|}
\hline & \multicolumn{11}{|c|}{ Параметри задоволеності працею } \\
\hline & 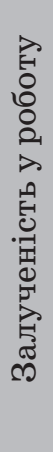 & 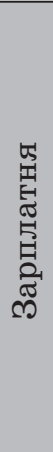 & 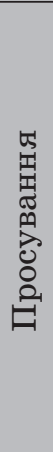 & 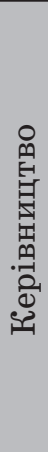 & 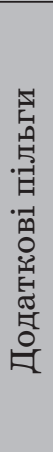 & 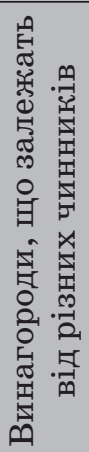 & 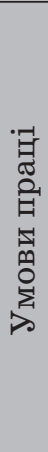 & 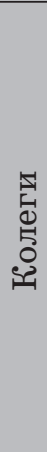 & 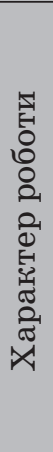 & 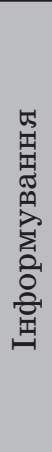 & 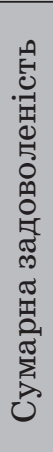 \\
\hline $\begin{array}{c}\text { Сумарна } \\
\text { ефектив- } \\
\text { ність }\end{array}$ & 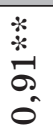 & $\begin{array}{l}* \\
\infty \\
10 \\
0\end{array}$ & $\frac{*}{0}$ & م્ & 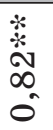 & $\begin{array}{l}* \\
* \\
\vdots \\
\infty \\
0 \\
0\end{array}$ & $\stackrel{a}{a}$ & $\frac{+1}{\stackrel{+}{0}}$ & 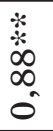 & $\begin{array}{l}10 \\
0 \\
0\end{array}$ & \begin{tabular}{l}
$*$ \\
$*$ \\
\multirow{2}{*}{} \\
0 \\
0 \\
0
\end{tabular} \\
\hline
\end{tabular}

Примітка: * за р $\leq 0,05 ; * *$ за $\mathrm{p} \leq 0,001$.

Слюсарі, які демонструють високий рівень задоволеності власною професійною діяльністю, цінують додаткові пільги, що їм надає роботодавець; також важливими для них є можливість отримання різноманітних винагород, характер праці, зарплатня і просування. Вони ефективніші у роботі та мають високий рівень залученості до своєї справи.

Показово, що не встановлено зв'язку між такими параметрами задоволеності робітників, як задоволеність умовами праці, стосунками з колегами й інформуванням.

Робота слюсаря з ремонту газового устаткування у державній установі передбачає невизначеність, часті цейтноти й екстреність запитів на послуги. До речі, в іншому нашому дослідженні було емпірично доведено зв' язок оцінки ефективності слюсарів з їх фрустраційною толерантністю. Тому варто припустити, що працівники, які обирають таку 
роботу і в результаті можуть ставати на ній ефективними, усвідомлюють усі потенційні складнощі, готові до них і напрацьовують певні механізми їх опанування.

Наступним кроком аналізу емпіричних даних було співставлення груп досліджуваних, виокремлених за середньогруповим рівнем задоволеності працею за допомогою критерія кутового перетворення $\varphi$ *-Фішера між групою високозадоволених фахівців і фахівців із низьким рівнем задоволеності роботою.

Отримані дані свідчать про те, що працівникам із високими показниками задоволеності роботою притаманні вищі рівні ефективності $(\varphi *=4,234$ за $\mathrm{p} \leq 0,01)$. Результати пошуку розбіжностей серед цих двох груп досліджуваних також указують і на те, що працівникам із високими показниками задоволеності роботою властиві вищі рівні залученості до роботи $(\varphi *=4,588$ за $\mathrm{p} \leq 0,01)$. А результати співставлення груп досліджуваних, виокремлених за цим критерієм між групою більш ефективних працівників і працівників із низьким рівнем ефективності, демонструють, що для більш ефективних фахівців теж характерні вищі рівні залученості до роботи $\left(\varphi^{*}=3,989\right.$ за $\left.\mathrm{p} \leq 0,01\right)$.

Отже, дані проведеного емпіричного дослідження дають змогу констатувати наявність зв'язку між ефективністю та задоволеністю роботою представників групи професій «людина - техніка».

Аналізуючи особливості задоволеності роботою та ефективності слюсарів із ремонту й експлуатації газового устаткування, можна помітити, що у деяких випадках працівники, які потенційно можуть бути ефективними у роботі, мають як низькі оцінки ефективності роботи, так і задоволеності працею.

Розглядаючи це питання детальніше, стає зрозуміло, що вони дуже низько оцінюють сам функціональний зміст і характер діяльності, а також винагороди, що залежать від гарного виконання робочих обов'язків. На задоволеність також впливає мотивація й амбіції робітника. Неза- 
доволений собою фахівець часто незадоволений і власною діяльністю.

Емоційно невитривала людина може мати хитке оціночне ставлення до своєї професійної діяльності, внаслідок чого можна побачити її невисоку задоволеність працею, яку треба виконати.

Важливо зазначити, що задоволеність роботою може бути причиною просоціальної поведінки; незадоволеність роботою здатна вилитися в контрпродуктивну поведінку, що заважає успіху в досягненні цілей організації. Такі результати узгоджуються з наведеними теоретичними відомостями щодо важливості у діяльності працівника таких чинників, як мотивація, ставлення до праці на суспільному (як до профресії, виду діяльності) й індивідуальному (як до конкретно виконуваної роботи) рівнях, оскільки на основі цих положень і формується ставлення до праці, що у підсумку пов' язано з ефективністю.

Вивчаючи задоволеність роботою працівників, можна прослідкувати, що деякі задоволені фахівці можуть мати значно нижчу ефективність, що пов'язано з нижчим рівнем їх технічних здібностей порівняно з більш ефективними колегами, проте їхня ефективність у роботі вища, ніж у колег, які мають подібний рівень професійних здібностей. Для таких фахівців притаманний високий рівень задоволеності, оскільки вони більш високо оцінюють характер роботи, високо оцінюючи такий вид професійної діяльності. Важливим є те, що для здійснення ефективної професійної діяльності суб’єкту праці необхідна сукупність знань, умінь, навичок, способів діяльності, професійно важливих психологічних якостей.

Отже, гіпотези нашого дослідження підтверджено, отримані результати проінтерпретовано.

\section{Висновки}

Проблема ефективності та задоволеності професійною діяльністю представників групи професій «людина - тех- 
ніка» є актуальною. Ефективність фахівців такої групи професій, зокрема слюсарів із ремонту й експлуатації газового устаткування, - це якісна інтегральна характеристика особистості робітника, що визначає його готовність і здатність до проведення технічних робіт у галузі ремонту й експлуатації газового устаткування, прийняття оптимальних рішень із застосуванням професійних знань і попереднього досвіду для досягнення потрібного результату, а також особиста відповідальність за прийняті рішення.

Задоволеність працею, її забезпечення, оцінювання та підвищення є важливими питаннями для підприємств у тому значенні, що задоволений персонал - це запорука успіху компанії. Задоволення працею - це співвідношення певних запитів працівника щодо умов, змісту, оплати праці з існуючими умовами на підприємстві. Тобто, це суб'єктивна оцінка працівником своїх запитів щодо умов на підприємстві, у яких він виконує свої професійні обов'язки.

Розрізняють такі детермінанти задоволеності роботою: рівень задач, із якими фахівець спроможний успішно впоратися; особиста цікавість до самого процесу роботи; наявність відзнак за належно виконану роботу та відповідно до ступеня очікувань робітника; наявність інструментів і пристроїв, що слугують для полегшення виконання завдань; високий рівень самооцінки професійних знань, умінь і навичок; відчуття взаємопідтримки між колегами по роботі під час реалізації спеціальних задач у важких епізодах праці.

Теоретичне й емпіричне дослідження уможливлює виокремлення таких чинників задоволеності роботою, що найбільше пов'язані з їі ефективністю: характер роботи; заробітна платня; додаткові пільги; стосунки з керівництвом; перспективи просування в кар'єрі.

Результати нашого емпіричного дослідження вказують на те, що працівникам із високими показниками задоволеності роботою притаманні вищі рівні ефективності. Крім 
того, можна зробити висновок, що для більш ефективних фахівців характерні вищі рівні залученості до роботи.

Діагностика чинників, які позитивно чи негативно впливають на ставлення фахівців до своєї праці, є передумовою прийняття зважених управлінських рішень у сфері управління персоналом, підвищення продуктивності праці й ефективності діяльності підприємства.

Перспективи подальших досліджень пов'язані зі створенням шкали оцінки показників продуктивності праці представників групи професій «людина - техніка», що не тільки впливають на адаптацію до професійної діяльності й оволодіння професійними обов' язками відповідно до вимог роботодавців, а також дають змогу оцінювати та прогнозувати ефективність діяльності.

\section{Література}

Зимняя И. А. Ключевые компетентности как результативно-целевая основа компетентностного подхода в образовании. Авторская версия. Москва : Исследовательский центр проблем качества подготовки специалистов, 2004. 40 с.

Мадди С. Смыслообразование в процессе принятия решений. Психологический журнал. Москва : ИП РАН, 2005. № 26 (6). С. 87-101.

Онуфрієва Л. А. Теоретико-методологічні засади професійної зрілості особистості фахівців соціономічних професій. Проблели сучасної психологї: Збірник наукових праць Кал'янець-Подільського наиіонального університету ілені Івана Огієнка, Інституту психологї ілені Г. С. Костюка НАПН України / За наук. ред. С. Д. Максименка, Л. А. Онуфрієвої. Вип. 31. Кам'янець-Подільський : Акcioma, 2016. C. 257-271.

Онуфрієва Л. А. The theoretical and methodological analysis of Me-professional image as a component of future professionals' Me-concept. Проблели сучасної психології: Збірник наукових праць Кам'янець-Подільського національного університету ілені Івана Огієнка, Інституту психологї̈ ілені Г. С. Костюка НАПН України / За наук. ред. С. Д. Максименка, Л. А. Онуфрієвої. Вип. 39. Кам'янець-Подільський : Аксіома, 2018. С. 195-205. DOI 10.32626/22276246.2018-39.195-205.

Панок В. Г., Чепелєва Н. В. Професійний відбір. Основи практичної психології. Київ : Либідь, 1999. С. 228-236. 
Равен Дж. Компетентность в современном обществе. Москва : КогитоЦентр, 2002. 185 с.

Статінова Н. П., Радченко С. Г. Етика бізнесу. Київ, 2001. 280 с.

Штепа О. С. Головні ідеї інтенціональної концепції особистісного самоздійснення. Проблели сучасної психологї: Збірник наукових праць Кал'янець-Подільського національного університету ілені Івана Огієнка, Інституту психологї ілені Г. С. Костюка НАПН України / За ред. С. Д. Максименка, Л. А. Онуфрієвої. Вип. 41. Кам'янець-Подільський : Аксіома, 2018. С. 442-461.

Kaap-Deeder, J., de Houwer, J., Hughes, S., Spruyt, A. , \& Vansteenkiste, M. (2018). The development and validation of an implicit measure of competence need satisfaction. Motivation and emotion, 42 (5), 615637. Retrieved from https://doi.org/10.1007/s11031-018-9685-3.

Mansfield, R. S. (1996). Building Competency Models: Approaches for HR Professionals. Human Resource Management, 35 (1), 7-18. Retrieved from https://pdfs.semanticscholar.org/91d6/2eceb2b428 8bde92b46f4c58c9dc5bcf9827.pdf.

Ryff, C. (1995). The structure of psychological well-being revisited. Journal of Personality and Social Psychology, 69, 719-727.

\section{References}

Zimnjaja, I. A. (2004). Kljuchevye kompetentnosti kak rezul'tativno-celevaja osnova kompetentnosnogo podhoda v obrazovanii. Avtorskaja versija [Key competencies as an effective target basis of a competence-based approach in education. Author's version]. Moskva : Issledovatel'skij centr problem kachestva podgotovki specialistov [in Russian].

Maddi, S. (2005). Smysloobrazovanie v processe prinjatija reshenij [Meaning in the decision-making process]. Psihologicheskij zhurnal-Psychological Journal, 26 (6), 87-101. Moscow : IP RAN [in Russian].

Onufriieva, L. A. (2016). Teoretyko-metodolohichni zasady profesiinoi zrilosti osobystosti fakhivtsiv sotsionomichnykh profesii [Theoretical and methodological principles of professional maturity of socionomic specialist's personality]. Problemy suchasnoi psykholohii: Zbirnyk naukovykh prats Kamianets-Podilskoho natsionalnoho universytetu im. I. Ohiienka, Instytutu psykholohii imeni H. S. Kostiuka NAPN Ukrainy - Problems of Modern Psychology: Collection of Research Papers of Kamianets-Podilskyi Ivan Ohienko National University and G. S. Kostiuk Institute of Psychology of NAPS of Ukraine, 31, 257-271. Kamianets-Podilskyi : Aksioma [in Ukrainian].

Onufriieva, L. A. (2018). The theoretical and methodological analysis of Me-professional image as a component of future professionals' $\mathrm{Me}$ concept. Problemy suchasnoi psykholohii: Zbirnyk naukovykh prats 
Kamianets-Podilskoho natsionalnoho universytetu im. I. Ohiienka, Instytutu psykholohii imeni H. S. Kostiuka NAPN Ukrainy - Problems of Modern Psychology: Collection of Research Papers of Kamianets-Podilskyi National Ivan Ohiienko University and G. S. Kostiuk Institute of Psychology of the NAES of Ukraine, 39, 195-205. Kamianets-Podilskyi : Aksioma [in Ukrainian]. DOI 10.32626/22276246.2018-39.195-205.

Panok, V. H., \& Chepelieva, N. V. (1999). Profesiinyi vidbir [Professional selection]. Osnovy praktychnoi psykholohii - The fundamentals of applied psychology, 228-236. Kyiv : Lybid [in Ukrainian].

Raven, Dzh. (2002). Kompetentnost'v sovremennom obshchestve [Competence in modern society]. Moskva : Kogito-Centr [in Russian].

Statinova, N. P., \& Radchenko, S. H. (2001). Etyka biznesu [Ethics of business ]. Kyiv [in Ukrainian].

Shtepa, O. S. (2018). Holovni idei intentsionalnoi kontseptsii osobystisnoho samozdiisnennia [The Main Ideas of the Intentional Concept of Personality-Based Self-Realization]. Problemy suchasnoi psykholohii: Zbirnyk naukovych prats Kamianets-Podilskoho natsionalnoho universytetu imeni Ivana Ogiienka, Instytutu psykholohii imeni H. S. Kostiuka NAPN Ukrainy - Problems of modern psychology: Collection of research papers of Kamianets-Podilskyi National Ivan Ohiienko University, G. S. Kostiuk Institute of Psychology of the NAES of Ukraine, 41, 442-461. Kamianets-Podilskyi : Aksioma [in Ukrainian].

Kaap-Deeder, J., de Houwer, J., Hughes, S., Spruyt, A., \& Vansteenkiste, M. (2018). The development and validation of an implicit measure of competence need satisfaction. Motivation and emotion, 42 (5), 615637. Retrieved from https://doi.org/10.1007/s11031-018-9685-3.

Mansfield, R. S. (1996). Building Competency Models: Approaches for HR Professionals. Human Resource Management, 35 (1), 7-18. Retrieved from https://pdfs.semanticscholar.org/91d6/2eceb2b428 8bde92b46f4c58c9dc5bcf9827.pdf.

Ryff, C. (1995). The structure of psychological well-being revisited. Journal of Personality and Social Psychology, 69, 719-727.

\section{АНОТАЦІЯ}

Проаналізовано особливості зв'язку між оцінкою ефективності та задоволеністю роботою представників групи професій «людина - техніка» на прикладі слюсарів із ремонту й експлуатації газового устаткування. Для визначення особливостей зв'язку між оцінкою ефективності та задоволеністю роботою представників групи професій «людина - техніка» було використано комплекс таких психодіагностичних 
інструментів: "Опитувальник залученості у роботу» (Job Involvement Questionnaire; JIQ) Н. Канунго; "Опитувальник задоволеності роботою» (Job Satisfaction Survey; JSS) P. Спектора; для оцінки ефективності робітників використаний опитувальник, розроблений менеджером по роботі з персоналом ПАТ «Дніпрогаз» М. А. Шевченком. Методи емпіричного дослідження умішували дескриптивну статистику, кореляційний аналіз за критерієм $\rho$-Спірмена, а також пошук розбіжностей між контрастними підгрупами досліджуваних за критерієм кутового перетворення $\varphi^{*}$-Фішера. У дослідженні взяли участь 40 слюсарів із ремонту й експлуатації газового устаткування та чотири їх керівники. У результаті було виявлено зв'язок рівня оцінки ефективності з рівнем задоволеності роботою і залученості у роботу. Такі чинники задоволеності роботою, як характер роботи, заробітна платня, додаткові пільги, перспективи просування у кар'єрі, пов'язані з оцінкою ефективності й, водночас, як виявилось, умови роботи, стосунки з керівництвом і колегами з нею не пов'язані.

Практичне застосування результатів дослідження полягає у їхній потенційній цінності для менеджерів із персоналу ma HR-відділів підприємств із метою пошуку співробітників, які краще підходять для такої групи професій, а також із метою мотивації, підвищення задоволеності й ефективності вже працюючих фахівців.

Ключові слова: задоволеність роботою, оцінка ефективності, продуктивність, залученість у роботу, представники групи професій «людина - техніка».

Моцная Светлана, Байер Оксана. Особенности связи между удовлетворенностью работой и оценкой эффективности представителей группы профессий «человек - техника»

\section{АННОТАЦИЯ}

Проанализированы особенности связи между оценкой эффрективности и удовлетворенностью работой представителей группы профессий "человек - техника» на примере слесарей по ремонту и эксплуатации газового оборудования. Для определения особенностей связи между оценкой эффективности и удовлетворенностью работой представителей группы профессий "человек - техника» был использован комплекс следующих психодиагностических инструментов: "Опросник вовлеченности в работу» (Job Involvement Questionnaire; JIQ) Н. Канунго; "Опросник удовлетворенности работой» (Job Satisfaction 
Survey; JSS) Г. Спектра; для оценки эффрективности рабочих использован опросник, разработанный менеджером по работе с персоналом ОАО «Днепрогаз» М. А. Шевченко. Методы эмпирического исследования включали дескриптивную статистику, корреляционный анализ по критерию $\rho$-Спирмена, а также поиск разногласий между контрастными подгруппами испытуемых по критерию углового преобразования $\varphi^{*}$-Фишера. В исследовании приняли участие 40 слесарей по ремонту и эксплуатации газового оборудования и четыре их руководителя. $B$ результате была выявлена связь уровня оценки эфррективности с уровнем удовлетворенности работой и вовлеченности в работу. Такие факторы удовлетворенности работой, как характер работы, заработная плата, дополнительные льготы, перспективы продвижения в карьере связаны с оценкой эффективности и, одновременно, как оказалось, условия работы, отношения с руководством и коллегами с ней не связаны.

Практическое применение результатов исследования заключается в их потенциальной ценности для менеджеров по персоналу и $H R$ отделов предприятий с целью поиска сотрудников, которые лучше подходят для такой группы профессий, а также с целью мотивации, повышения удовлетворенности и эффективности уже работающих специалистов.

Ключевые слова: удовлетворенность работой, оценка эффективности, производительность, приверженность организации, представители группы профрессий «человек-техника». 